\title{
PENINGKATAN PRODUKTIVITAS PADI DI PROVINSI RIAU MELALUI PERBAIKAN SISTEM TANAM
}

\author{
Masganti ${ }^{1)}$ \\ ${ }^{1}$ Balai Penelitian Pertanian Lahan Rawa \\ Jln. Kebun Karet, Loktabat Utara, Banjarbaru 70712. Kalimantan Selatan \\ Telp/Fax: (0511) 4772534, email: balittra@ litbang.pertanian.go.id \\ Email: masgambut59@yahoo.com
}

\begin{abstract}
High population growth and low consumption of carbohydrate sources in Riau Province encourage rice production to be increased. One effort to increase rice production in Bumi Lancang Kuning is to increase productivity through improved planting systems. The research was conducted in the rainy season of 2016 on irrigated and tidal paddy field using Inpari 13 variety, aiming to determine the best planting system in increasing Riau Province rice productivity. Irrigated rice field is located in Dayang Suri Village, Bunga Raya Subdistrict, and tidal land is located in Selat Guntung Village, Sabak Auh Subdistrict, Siak Regency, Riau Province. The three planting systems tested were (1) tiles, (2) Jarwo 4: 1, and (3) Jarwo 2: 1 and two agroecosystems ie (a) tidal land and (b) irrigated land. The treatment was arranged in a randomized block design (RBD) with five replications. Fertilization $\mathrm{N}, \mathrm{P}_{2} \mathrm{O}_{5}$, and $\mathrm{K}_{2} \mathrm{O}$ for irrigated land (67.5-60-45) and tides (90-120-60). The parameters observed were plant height and number of tillers 30 and 60 days after planting (DAP), number of grain per panicle, weight of 1,000 grains, and rice productivity ( $t / h a)$. The results showed that plant height and number of tillers of 30 DAP were not affected by treatment, while the plant height, number of tillers at $60 \mathrm{DAP}$, the number of grains per panicle, and the weight of 1,000 grains were affected only by agro-ecosystem. Rice productivity is strongly influenced by agro-ecosystem and planting system. The productivity of rice in tidal land is lower than irrigated land. Compared with tile planting systems, the increased productivity of the Jarwo 2: 1 planting system is higher than the Jarwo 4: 1 planting system. Increased productivity due to improved planting systems in tidal areas is higher than irrigated land.
\end{abstract}

Keywords: Improvement, planting system, agroecosystem, productivity, rice, Riau

\section{PENDAHULUAN}

Pertambahan penduduk Provinsi Riau masih tergolong tinggi yakni sekitar 4,5\% per tahun (BPS Provinsi Riau, 2015). Pertambahan tersebut bersumber dari kelahiran yang berasal dari penduduk lokal dan urban, terutama yang bekerja dalam sektor perkebunan kelapa sawit, dan pelayanan jasa. Selain itu, masih rendahnya diversifikasi konsumsi sumber karbohidrat turut mendorong harus tersedianya beras dalam jumlah yang lebih banyak, padahal kemampuan provinsi ini memasok beras baru sekitar 43\% dari kebutuhan warganya (Masganti et al., 2016; Nurhayati et al., 2016). Apalagi menurut laporan BPS (2020) produksi beras Provinsi Riau pada tahun 2019 mengalami penurunan sebesar 20.270 ton $(13,33 \%)$ dibanding tahun 2018.

Peningkatan produksi padi di provinsi ini dapat dilakukan melalui pemanfaatan lahan pasang surut (Masganti et al., 2016; Nurhayati et al., 2016; Hairani et al., 2017) dan penggunan varietas unggul (Sutarno, 2012; Koesrini et al., 2013; Helmi, 2015; Rina dan Koesrini, 2016). Sejak tahun 2010, pemerintah Provinsi Riau telah melakukan langkah-langkah untuk meningkatkan kapasitas produksi padi melalui program Operasi Pangan Riau Makmur (Masganti et al., 2014; 2016; Nurhayati et al., 2016). Akan tetapi usaha ini belum memadai mengingat cepatnya laju alih fungsi lahan sawah menjadi perkebunan kelapa sawit (Mulyani et al., 2016), sementara kemampuan 
mencetak sawah juga sangat terbatas. Masalah lain yang dihadapi adalah menurunnya kesuburan tanah, menurunnya kapasitas fungsi sarana pengairan, meningkatnya frekuensi kejadian iklim ekstrem, dan masih rendahnya penerapan teknologi (Achmad, 2012; Masganti, 2013; Bustaman, 2014).

Produksi padi yang rendah di Provinsi Riau juga berkaitan erat dengan adanya usahatani sampingan seperti kelapa dan pinang. Kondisi ini menyebabkan petani tidak fokus ke usahatani padi, apalagi jika harga pinang atau kelapa sedang meningkat, maka usahatani padi menjadi tidak diutamakan (Nurhayati et al., 2016; Dinas Tanaman Pangan Hortikultura dan Perkebunan Provinsi Riau, 2017).

Tidak intensifnya petani dalam budidaya padi juga menyebabkan pemanfaatan lahan menjadi tidak optimal, sehingga sebagian terlantar dan indeks pertanaman (IP) rendah, sebagian besar sawah hanya ditanami satu kali dalam setahun (Masganti, 2010; Nuryanti dan Swastika, 2011; Masganti et al., 2014). Pada kondisi demikian, pembukaan lahan menjadi masalah karena teknologi tanpa bakar tidak dapat diterapkan akibat semak belukar yang tumbuh lebat, sementara pembukaan lahan dengan cara membakar tidak dibolehkan.

Peningkatan produksi padi di Provinsi Riau dapat dilakukan antaranya melalui peningkatan produktivitas yang didukung oleh ketersediaan teknologi menyangkut varietas, pengelolaan lahan, pengelolaan air, penggunaan sistem tanam, pemupukan, dan pengendalian organisme penggangu tanaman (OPT). Hal tersebut harus didukung dengan mengoptimalkan peran penyuluh swasta (Syahyuti, 2014), mempermudah akses penyuluh ke desa-desa sasaran melalui perbaikan fasilitas transportasi (Achmad, 2012), dan memberdayakan kelompoktani sebagai pelaku pembangunan pertanian (Nuryanti dan Swastika, 2011).

Salah satu potensi sumberdaya yang dapat dimanfaatkan untuk peningkatan produksi padi di Provinsi Riau adalah lahan rawa pasang surut. Menurut BBSDLP (2020), provinsi ini memiliki potensi lahan rawa pasang surut seluas 640.693 ha, akan tetapi baru dimanfaatkan untuk dua kali tanam padi seluas 36.608 ha, dan satu kali tanam padi 6.101 ha (Nurhayati et al., 2016). Berkaitan dengan peningkatan produktivitas padi melalui perbaikan sistem tanam, berbagai laporan menyebutkan bahwa penggunaan sistem tanam jajar legowo (Jarwo) meningkatkan produktivitas (Gimateri dan Yurzak, 2013; Erythrina dan Zaini, 2014; Sarlan, 2014). Peningkatan produktivitas akibat penggunaan sistem tanam Jarwo banyak dilaporkan dalam budidaya padi di lahan sawah irigasi. Oleh karena itu khasiat sistem tanam Jarwo juga perlu diuji di lahan sawah pasang surut.

Penelitian ini bertujuan untuk menentukan sistem tanam yang terbaik dalam meningkatkan produktivitas padi yang dibudidayakan di lahan sawah irigasi dan lahan sawah pasang surut Provinsi Riau.

\section{BAHAN DAN METODE}

\section{Waktu dan Tempat Penelitian}

Penelitian dilaksanakan pada musim hujan (MH) tahun 2016 di lahan sawah irigasi dan sawah pasang surut Kabupaten Siak, Provinsi Riau. Pengujian sistem tanam padi di lahan sawah irigasi berlokasi di Desa Dayang Suri, Kecamatan Bunga Raya, dan di lahan pasang surut berlokasi di Desa Selat Guntung, Kecamatan Sabak Auh.

\section{Rancangan Percobaan}

Penelitian menguji dua faktor, faktor pertama agroekosistem $(\mathrm{A})$, terdiri dari; sawah irigasi $\left(\mathrm{A}_{1}\right)$ dan sawah pasang surut $\left(\mathrm{A}_{2}\right)$. Faktor kedua adalah sistem tanam (S), terdiri dari; tegel $\left(\mathrm{S}_{1}\right)$, Jarwo 4:1 $\left(\mathrm{S}_{2}\right)$ dan Jarwo 2:1 $\left(\mathrm{S}_{3}\right)$. Perlakuan ditata dalam rancangan acak kelompok (RAK) dengan lima ulangan.

Varietas padi yang digunakan dalam penelitian ini adalah Inpari 13 dengan pertimbangan bahwa varietas ini banyak ditanam oleh petani baik di lahan irigasi maupun pasang surut. Persemaian padi yang ditanam dengan sistem tegel diawali dengan merendam benih selama 24 jam diikuti dengan inkubasi selama 48 jam. Benih yang sudah berkecambah ditebar secara merata di atas permukaan tanah dalam persemaian basah yang dikelilingi dengan parit drainase.

Persemaian padi yang dibudidayakan dengan sistem Jarwo dilakukan menggunakan dapog, dimana benih terlebih dahulu direndam selama 48 jam, kemudian ditiriskan. Selanjutnya benih disebar merata pada kotak dapog berukuran $18 \mathrm{~cm}$ x $56 \mathrm{~cm}$ dengan kepadatan benih $100-125 \mathrm{~g} /$ kotak. 
Penyiapan lahan dilakukan dengan cara basah, yakni tanah digenangi air setinggi 2-5 $\mathrm{cm}$ selama 2-3 hari. Selanjutnya tanah dibajak menggunakan traktor dengan kedalaman $15-20 \mathrm{~cm}$ dan diinkubasi selama 2-3 hari. Tanah kembali digenangi setinggi $2-5 \mathrm{~cm}$ selama 2-3 hari. Selanjutnya dilakukan pembajakan untuk melumpurkan tanah, kemudian diratakan. Tanah dibiarkan dalam kondisi lembab atau tidak tergenang.

Bibit yang berumur 14 hari sesuai dengan sistem tanam ditanam dalam petakan berukuran $20 \mathrm{~m}$ x $25 \mathrm{~m}$. Penanaman dengan sistem tegel dilakukan dengan jarak tanam $25 \mathrm{~cm}$ x $25 \mathrm{~cm}$. Sedangkan sistem tanam Jarwo 2:1 dilakukan dengan jarak tanam $25 \mathrm{~cm} \times 12,5 \mathrm{~cm} \times 50 \mathrm{~cm}$, artinya jarak antarbaris (hanya 2 baris) adalah $25 \mathrm{~cm}$, jarak antar tanaman $12,5 \mathrm{~cm}$ dan jarak antar tanaman pinggir adalah 50 cm, sedangkan sistem Jarwo 4:1 sama dengan Jarwo 2:1, tetapi dalam 4 (empat) baris terdapat 2 (dua) baris tanaman yang jarak antar tanamannya adalah $25 \mathrm{~cm}$. Caplak digunakan untuk membantu membuat tanda jarak tanam yang seragam dan teratur.

Pemupukan dilakukan untuk memenuhi kebutuhan hara N, P, dan K. Pupuk N bersumber dari urea, pupuk $\mathrm{P}$ bersumber dari SP-36, dan pupuk $\mathrm{K}$ bersumber dari $\mathrm{KCl}$. Dosis pupuk $\mathrm{N}_{2} \mathrm{P}_{2} \mathrm{O}_{5}$, dan $\mathrm{K}_{2} \mathrm{O}$ (90-60-60 kg/ha) untuk lahan pasang surut (67,5-60$45 \mathrm{~kg} / \mathrm{ha}$ ) untuk lahan irigasi berdasarkan anjuran Nurhayati et al. (2012). Pupuk susulan N didasarkan atas hasil uji menggunakan bagan warna daun (BWD) yang direkomendasikan oleh Erythrina (2016). Pupuk $\mathrm{K}$ diberikan dua kali, masing-masing 50\% dosis bersama dengan $50 \%$ dosis pupuk $\mathrm{N}$ dan semua pupuk $\mathrm{P}$ pada saat tanam, sisanya diberikan bersama dengan sisa dosis pupuk $\mathrm{N}$ pada saat tanaman berumur 40 hari sesudah tanam (HST).

\section{Pengumpulan Data}

Pengamatan dilakukan terhadap sifat kimia tanah sebelum pelaksanaan penelitian dengan mengambil contoh tanah pada kedalaman 0-20 cm menggunakan bor di lima titik, kemudian disatukan sebagai pewakil sampel tanah. Sifat kimia tanah yang dianalisis meliputi $\mathrm{pH}\left(\mathrm{H}_{2} \mathrm{O}\right)$, C-organik, $\mathrm{N}$-total, $\mathrm{P}$ tersedia, (Ca, Mg, K, Na)-tertukar, dan KTK. Metode analisis sifat kimia tanah yang digunakan diperlihatkan dalam Tabel 1.
Tabel 1. Metode analisis sifat kimia tanah lokasi penelitian

\begin{tabular}{|c|c|c|}
\hline No. & Jenis analisis & Metode analisis \\
\hline 1. & $\mathrm{pH}\left(\mathrm{H}_{2} \mathrm{O}\right)$ & $\begin{array}{l}\text { pH meter (Eviati dan } \\
\text { Sulaiman, 2009) }\end{array}$ \\
\hline 2. & C-organik (\%) & $\begin{array}{l}\text { Wakley \& Black (Eviati } \\
\text { dan Sulaiman, 2009) }\end{array}$ \\
\hline 3. & N-total (\%) & $\begin{array}{l}\text { Kjeldahl (Eviati dan } \\
\text { Sulaiman, 2009) }\end{array}$ \\
\hline 4. & $\begin{array}{l}\text { P-tersedia }\left(\mu \mathrm{g} \cdot \mathrm{g}^{-}\right. \\
\left.{ }^{1}\right)\end{array}$ & $\begin{array}{l}\text { BrayII-Olsen (Eviati dan } \\
\text { Sulaiman, 2009) }\end{array}$ \\
\hline 5. & $\begin{array}{l}\text { Ca-tertukar } \\
\left(\mathrm{cmol}(+) \cdot \mathrm{kg}^{-1}\right)\end{array}$ & $\begin{array}{l}\mathrm{NH}_{4} \mathrm{OAc} 1,0 \mathrm{~N} \text { (Eviati dan } \\
\text { Sulaiman, 2009) }\end{array}$ \\
\hline 6. & $\begin{array}{l}\text { Mg-tertukar } \\
\left(\mathrm{cmol}(+) \cdot \mathrm{kg}^{-1}\right)\end{array}$ & $\begin{array}{l}\mathrm{NH}_{4} \mathrm{OAc} 1,0 \mathrm{~N} \text { (Eviati dan } \\
\text { Sulaiman, 2009) }\end{array}$ \\
\hline 7. & $\begin{array}{l}\text { K-tertukar } \\
\left(\mathrm{cmol}(+) \cdot \mathrm{kg}^{-1}\right)\end{array}$ & $\begin{array}{l}\mathrm{NH}_{4} \mathrm{OAc} 1,0 \mathrm{~N} \text { (Eviati dan } \\
\text { Sulaiman, 2009) }\end{array}$ \\
\hline 8. & $\begin{array}{l}\text { Na-tertukar } \\
\left(\mathrm{cmol}(+) \cdot \mathrm{kg}^{-1}\right)\end{array}$ & $\begin{array}{l}\mathrm{NH}_{4} \mathrm{OAc} 1,0 \mathrm{~N} \text { (Eviati dan } \\
\text { Sulaiman, 2009) }\end{array}$ \\
\hline 9. & $\begin{array}{l}\text { KTK } \\
\left(\operatorname{cmol}(+) \cdot \mathrm{kg}^{-1}\right)\end{array}$ & $\begin{array}{l}\mathrm{NH}_{4} \mathrm{OAc} 1,0 \mathrm{~N} \text { (Eviati dan } \\
\text { Sulaiman, 2009) }\end{array}$ \\
\hline
\end{tabular}

Pengamatan dilakukan terhadap tinggi tanaman dan jumlah anakan umur 30 dan 60 HST, jumlah gabah isi per malai, bobot 1.000 butir gabah, dan produktivitas. Tinggi tanaman diukur dari permukaan tanah sampai bagian tertinggi tanaman, sedang jumlah anakan ditetapkan dengan menghitung seluruh anakan dalam satu rumpun dari 5 (lima) titik diagonal. Jumlah gabah isi per malai diambil dari 5 (lima) contoh malai, kemudian dipisahkan malai isi dan dihitung, kemudian dirata-ratakan. Bobot 1.000 butir gabah isi ditetapkan dengan mengambil 250 butir gabah isi, kemudian ditimbang dan dikonversi menjadi berat 1.000 butir, dinyatakan dalam satuan gram. Produktivitas padi dinyatakan dalam satuan t/ha. Data diperoleh dari tiga lokasi ubinan yang berukuran $25 \mathrm{~m}^{2}$ untuk setiap petakan, selanjutnya dirata-ratakan. Dengan luas ubinan tersebut diperoleh jumlah rumpun panen untuk sistem tanam tegel (400 rumpun), Jarwo 4:1 (560 rumpun) dan Jarwo 2:1 (640 rumpun).

Perrtumbuhan dan produktivitas tanaman padi dipengaruhi oleh efisiensi pemanfaatan hara. Tanaman yang lebih efisien memanfaatkan hara tumbuh lebih baik dan produktivitasnya lebih tinggi (Masganti, 2011). Efisiensi pemanfaatan hara (EPH) merupakan perbandingan antara produktivitas $\mathrm{x}$ populasi sistem tanam terhadap produktivitas $\mathrm{x}$ 
populasi sistem tanam tegel. Metode perhitungan $\mathrm{EPH}$ menggunakan rumus:

$\mathrm{EPH}=\frac{\text { produktivitas } \mathrm{x} \text { populasi sistem tanam Jarwo }}{\text { produktivitas } \mathrm{x} \text { populasi sistem tanam Tegel }} \times 100 \%$

\section{Analisis Data}

Analisis ragam digunakan untuk mengetahui pengaruh perlakuan, sedang untuk membedakan pengaruh antar perlakuan, dilakukan uji selisih ratarata terkecil (LSD) menurut prosedur yang dikemukakan oleh Gomez dan Gomez (1995).

\section{HASIL DAN PEMBAHASAN}

\section{Tipologi Lahan dan Sifat Kimia Tanah}

Lahan pasang surut yang terletak di Desa Selat Guntung, Kecamatan Sabak Auh tergolong lahan pasang surut sulfat masam dengan tipologi luapan B (Adimihardja et al., 1998). Lahan ini terairi pada saat sungai Siak mengalami pasang tunggal atau pasang besar. Lahan pasang surut dengan tipologi luapan B merupakan lahan yang banyak dimanfaatkan petani untuk budidaya padi (Masganti, 2013; Masganti et al., 2019).

Hasil analisis sifat kimia tanah lokasi penelitian menunjukkan bahwa tanah lokasi penelitian mengandung $\mathrm{C}$-organik yang rendah. Hal ini disebabkan petani tidak mengembalikan jerami ke dalam tanah, sehingga tanah mengalami pemiskinan C-organik. Hasil ini sejalan dengan hasil yang dikemukakan oleh Wahida (2014), Ompusunggu et al. (2015), dan Masganti et al. (2016). Pengembalian jerami padi ke dalam tanah, tidak saja mempertahankan kandungan C-organik dan ketersediaan hara lain seperti $\mathrm{N}$ dan $\mathrm{P}$, tetapi juga memperbaiki sifat fisik tanah dan meningkatkan produktivitas tanaman (Aislabie dan Dellipe, 2013; Dariah et al., 2015; Hartatik et al., 2015).

Tabel 2 juga menjelaskan bahwa tingkat kesuburan tanah di lahan irigasi lebih tinggi dari tanah di lahan pasang surut. Hal ini disebabkan kemasaman tanah di lahan pasang surut lebih tinggi (pH tanah lahan pasang surut berkategori sangat masam, sedang tanah lahan irigasi berkategori masam), sehingga ketersediaan hara lebih terbatas. Pirit menjadi sumber kemasaman di lahan pasang surut, jika tinggi air tanah berada di bawah lapisan pirit menyebabkan terjadinya oksidasi pirit yang melepaskan sejumlah ion $\mathrm{H}^{+}$(Hairani et al., 2017; Masganti et al., 2019). Oleh karena itu untuk memperoleh produksi padi yang maksimal, Anwar dan Mawardi (2012), Alwi dan Nazemi (2013), dan Masganti et al. (2015) mengusulkan pentingnya pengelolaan air di lahan pasang surut. Selain itu, tanah-tanah di lahan pasang surut mengandung $\mathrm{Al}$ dan Fe yang tinggi jika tidak dilakukan pengelolaan air yang tepat. Ketersediaan yang tinggi kedua unsur tersebut berpotensi mengikat $\mathrm{P}$, sehingga ketersediaan $\mathrm{P}$ dalam tanah menjadi terbatas (Masganti, 2010; Masganti et al., 2016).

Tabel 2 menginformasikan bahwa kategori kadar N-total dalam tanah pasang surut adalah rendah, sementara dalam tanah irigasi kategorinya sedang. Kadar P-tersedia dalam tanah pasang surut berkategori sangat rendah, sedangkan kadar P dalam tanah irigasi berkategori sedang. Demikian juga dengan kadar K-tertukar dalam tanah pasang surut berkategori rendah, sementara dalam tanah irigasi berkategori sedang. Perbedaan tersebut menyebabkan perbedaan dalam rekomendasi pemupukan NPK (Nurhayati et al., 2012; Husnain et al., 2016).

\section{Pertumbuhan Tanaman Padi}

Hasil analisis ragam terhadap tinggi tanaman umur 30 dan 60 HST menunjukkan bahwa kedua parameter tersebut sangat nyata dipengaruhi oleh agroekosistem dan sistem tanam yang digunakan. Tabel 3 menjelaskan bahwa padi varietas Inpari13 yang dibudidayakan di lahan pasang surut tumbuh lebih pendek, sedangkan perubahan sistem tanam dari tegel ke Jarwo menyebabkan penurunan tinggi tanaman.

Padi yang dibudidayakan di lahan pasang surut mengalami cekaman berkaitan dengan sifat kimia tanah (Wahida, 2014; Masganti et al., 2016; 2019). Perbedaan tersebut menyebabkan kemampuan menyerap hara menjadi berbeda (Masganti, 2011), sehingga tinggi tanaman tidak maksimal.

Penambahan populasi akibat perubahan sistem tanam menyebabkan kemampuan tanaman meninggi menjadi lebih rendah. Hasil ini sejalan dengan hasil yang dikemukakan oleh Mohaddesi et al. (2011), Mondal dan Putch (2013), dan Nakano et al. (2014).

Data dalam Tabel 4 menginformasikan bahwa jumlah anakan sangat nyata dipengaruhi hanya oleh agroekosistem. Kemampuan tanaman membentuk anakan lebih tinggi pada tanaman padi yang 
Tabel 2. Hasil analisis sifat kimia tanah lahan irigasi dan pasang surut lokasi Penelitian

\begin{tabular}{clcc}
\hline \multirow{2}{*}{ No. } & Sifat kimia dan satuan & \multicolumn{2}{c}{ Hasil dan kategori } \\
\cline { 3 - 4 } & & Lahan Irigasi & Lahan pasang surut \\
\hline 1. & $\mathrm{pH}\left(\mathrm{H}_{2} \mathrm{O}\right)$ & $5,3(\mathrm{M})$ & $4,6(\mathrm{SM})$ \\
2. & C-organik $(\%)$ & $1,56(\mathrm{R})$ & $1,92(\mathrm{R})$ \\
3. & N-total $(\%)$ & $0,33(\mathrm{~S})$ & $0,20(\mathrm{R})$ \\
4. & P-tersedia $\left(\mu \mathrm{g}^{-1}\right)$ & $16,9(\mathrm{~S})$ & $9,2(\mathrm{SR})$ \\
5. & Ca-tertukar $\left(\mathrm{cmol}(+) \cdot \mathrm{kg}^{-1}\right)$ & $3,12(\mathrm{R})$ & $2,14(\mathrm{R})$ \\
6. & Mg-tertukar $\left(\mathrm{cmol}(+) \cdot \mathrm{kg}^{-1}\right)$ & $1,12(\mathrm{~S})$ & $0,79(\mathrm{R})$ \\
7. & K-tertukar $\left(\mathrm{cmol}(+) \cdot \mathrm{kg}^{-1}\right)$ & $0,23(\mathrm{~S})$ & $0,16(\mathrm{R})$ \\
8. & Na-tertukar $\left(\mathrm{cmol}(+) \cdot \mathrm{kg}^{-1}\right)$ & $0,19(\mathrm{R})$ & $0,14(\mathrm{R})$ \\
9. & KTK $\left(\mathrm{cmol}(+) \cdot \mathrm{kg}^{-1}\right)$ & $23,57(\mathrm{~S})$ & $18,67(\mathrm{~S})$ \\
\hline
\end{tabular}

Keterangan: $\mathrm{M}=$ masam, $\mathrm{SM}=$ sangat masam, $\mathrm{R}=$ rendah, $\mathrm{S}=$ sedang, $\mathrm{SR}=$ sangat rendah

Tabel 3. Pengaruh sistem tanam dan agroekosistem terhadap tinggi tanaman padi varietas Inpari 13 umur 30 dan 60 HST $(\mathrm{cm})$

\begin{tabular}{lcccccc}
\hline \multirow{2}{*}{$\begin{array}{l}\text { Sistem } \\
\text { tanam }\end{array}$} & \multicolumn{2}{c}{ Agroekosistem dan tinggi tanaman 30 HST } & \multicolumn{3}{c}{ Agroekosistem dan tinggi tanaman 60 HST } \\
\cline { 2 - 7 } & Pasang surut & Irigasi & Rata-rata & Pasang surut & Irigasi & Rata-rata \\
\hline Tegel & 43,4 & 49,2 & $\mathbf{4 6 , 3 a}$ & 95,8 & 99,6 & $\mathbf{9 7 , 7 a}$ \\
Jarwo 4:1 & 41,5 & 45,7 & $\mathbf{4 3 , 6 b}$ & 93,3 & 97,2 & $\mathbf{9 5 , 3 b}$ \\
Jarwo 2:1 & 40,2 & 45,2 & $\mathbf{4 2 , 7 b}$ & 92,5 & 94,4 & $\mathbf{9 3 , 5 b}$ \\
\hline Rata-rata & $\mathbf{4 1 , 7} \mathbf{x}$ & $\mathbf{4 6 , 1 y}$ & $\mathbf{4 4 , 2}$ & $\mathbf{9 3 , 9 p}$ & $\mathbf{9 7 , 1 q}$ & $\mathbf{9 5 , 5}$ \\
\hline
\end{tabular}

Keterangan : Angka-angka dalam kolom dan baris rata-rata tinggi tanaman pada agroekosistem dan sistem tanam yang diikuti huruf yang sama tidak berbeda nyata menurut LSD 1\%

Tabel 4. Pengaruh sistem tanam dan agroekosistem terhadap jumlah anakan/rumpun tanaman padi varietas Inpari 13 umur 30 dan 60 HST

\begin{tabular}{lcccccc}
\hline \multirow{2}{*}{$\begin{array}{l}\text { Sistem } \\
\text { tanam }\end{array}$} & \multicolumn{2}{c}{ Agroekosistem dan jumlah anakan 30 HST } & \multicolumn{3}{c}{ Agroekosistem dan jumlah anakan 60 HST } \\
\cline { 2 - 7 } & Pasang surut & Irigasi & Rata-rata & Pasang surut & Irigasi & Rata-rata \\
\hline Tegel & 7,7 & 9,2 & $\mathbf{8 , 5 a}$ & 13,5 & 19,6 & $\mathbf{1 6 , 6 a}$ \\
Jarwo $4: 1$ & 7,5 & 8,6 & $\mathbf{8 , 1 a}$ & 13,1 & 18,8 & $\mathbf{1 6 , 0 a}$ \\
Jarwo $2: 1$ & 7,2 & 8,3 & $\mathbf{7 , 6}$ & 12,8 & 18,4 & $\mathbf{1 5 , 6 a}$ \\
\hline Rata-rata & $\mathbf{7 , 5 x}$ & $\mathbf{8 , 7 y}$ & $\mathbf{8 , 1}$ & $\mathbf{1 3 , 1 p}$ & $\mathbf{1 8 , 9 q}$ & $\mathbf{1 6 , 0}$ \\
\hline
\end{tabular}

Keterangan : Angka-angka dalam kolom dan baris rata-rata jumlah anakan pada agroekosistem dan sistem tanam yang diikuti huruf yang sama tidak berbeda nyata menurut LSD 1\%

dibudidayakan di lahan irigasi. Hal ini sangat terkait dengan lebih rendahnya kemampuan tanah di lahan pasang surut mensuplai hara bagi tanaman.

Berkurangnya kemampuan tanaman padi membentuk anakan jika ditanam di lahan pasang surut dapat dipahami mengingat tingkat kesuburan tanah yang lebih rendah (Tabel 2). Pasokan hara yang lebih terbatas menyebabkan tanaman padi tidak maksimal dalam membentuk anakan (Wahida, 2014; Masganti et al., 2016; Nurhayati et al., 2016).

Tidak berpengaruhnya perlakuan sistem tanam terhadap jumlah anakan mungkin disebabkan pertambahan populasi tanaman dari 160.000 tanaman/ha menjadi 213.333 tanaman/ha belum cukup atau belum mampu mengurangi secara nyata kemampuan tanaman membentuk anakan. Kemungkinan lain adalah karena parameter ini lebih 
adapted atau toleran dengan perubahan populasi. Akan tetapi dalam penelitian ini terlihat adanya pengurangan kemampuan tanaman membentuk anakan jika dilakukan perubahan sistem tanam dari tegel ke Jarwo. Hasil penelitian ini membuktikan bahwa peningkatan populasi tanaman padi dari tegel ke Jarwo masih bisa dilakukan.

Hasil penelitian ini juga membuktikan bahwa perubahan sistem tanam Jarwo meningkatkan efisiensi pemanfaatan hara. Tabel 5 memperlihatkan bahwa efisiensi pemanfaatan hara tanaman padi yang dibudidayakan dengan sistem tanama Jarwo 2:1 lebih tinggi dari sistem tanam Jarwo 4:1. Hal ini diduga akibat populasi yang lebih banyak dan lebih banyaknya tanaman pinggir yang dapat berfungsi sebagai "Barrier" bagi hara.

\section{Jumlah Gabah Isi per Malai dan Bobot 1.000 Butir Gabah}

Hasil analisis ragam menunjukkan bahwa jumlah gabah isi per malai dan bobot 1.000 butir gabah padi varietas Inpari 13 sangat nyata dipengaruhi hanya oleh lokasi (jenis lahan) tanaman padi dibudidayakan. Hal ini menegaskan bahwa pertambahan populasi akibat perubahan sistem tanam belum mampu mempengaruhi kemampuan tanaman padi menghasilkan jumlah gabah isi dan bobot 1.000 butir gabah yang berbeda. Meskipun terdapat kecenderungan bahwa perubahan sistem tanam dari tegel ke Jarwo menurunkan kapasitas tanaman padi menghasilkan gabah isi dan bobot 1.000 butir gabah.

Perubahan agroeksistem merupakan faktor yang sangat penting bagi tanaman padi dalam menghasilkan gabah isi yang lebih banyak dan bobot 1.000 butir gabah yang lebih berat. Perbedaan tingkat kesuburan tanah menjadi penyebab perbedaan dalam menghasilkan gabah isi dan bobot gabah (Mohaddesi et al., 2011; Giametri dan Yursak, 2013; Masganti et al., 2016). Salah satu unsur yang berperan dalam membentuk gabah isi dan bobot gabah adalah $\mathrm{P}$ yang ketersediaannya lebih rendah di lahan pasang surut (Tabel 2).

\section{Produktivitas Padi}

Hasil analisis ragam memperlihatkan bahwa sistem tanam dan agroekosistem berpengaruh sangat nyata terhadap produktivitas padi varietas Inpari 13 . Produktivitas padi yang dibudidayakan di lahan irigasi lebih tinggi dari lahan pasang surut, sedangkan sistem tanam tegel menghasilkan produktivitas yang paling rendah (Tabel 7).

Tabel 5. Pengaruh sistem tanam dan agroekosistem terhadap efisiensi pemanfaatan hara tanaman padi varietas Inpari 13

\begin{tabular}{lccc}
\hline \multirow{2}{*}{ Sistem Tanam } & \multicolumn{2}{c}{ Agroekosistem } & Rata-rata \\
\cline { 2 - 3 } & Pasang Surut & Irigasi & \\
\hline Tegel & $100,00 \%$ & $100,00 \%$ & $100,00 \%$ \\
Jarwo 4:1 & $136,93 \%$ & $123,00 \%$ & $129,97 \%$ \\
Jarwo 2:1 & $174,57 \%$ & $153,99 \%$ & $164,28 \%$ \\
\hline
\end{tabular}

Tabel 6. Pengaruh sistem tanam dan agroekosistem terhadap jumlah gabah per malai dan bobot 1.000 butir gabah padi varietas Inpari 13

\begin{tabular}{lcccccc}
\hline \multirow{2}{*}{$\begin{array}{l}\text { Sistem } \\
\text { tanam }\end{array}$} & \multicolumn{2}{c}{ Agroekosistem dan jumlah gabah isi per malai } & \multicolumn{3}{c}{ Agroekosistem dan bobot 1.000 butir $(\mathrm{g})$} \\
\cline { 2 - 6 } & Pasang surut & Irigasi & Rata-rata & Pasang surut & Irigasi & Rata-rata \\
\hline Tegel & 101,8 & 128,5 & $\mathbf{1 1 5 , 1 a}$ & 22,4 & 24,8 & $\mathbf{2 3 , 6 a}$ \\
Jarwo $4: 1$ & 99,9 & 124,9 & $\mathbf{1 1 2 , 4 a}$ & 22,0 & 24,3 & $\mathbf{2 3 , 2 a}$ \\
Jarwo $2: 1$ & 98,1 & 123,9 & $\mathbf{1 1 1 , 0 a}$ & 21,5 & 23,8 & $\mathbf{2 2 , 7 a}$ \\
\hline Rata-rata & $\mathbf{9 9 , 9 x}$ & $\mathbf{1 2 5 , 8 y}$ & $\mathbf{1 1 2 , 8}$ & $\mathbf{2 2 , 0 r}$ & $\mathbf{2 4 , 3 s}$ & $\mathbf{2 3 , 2}$ \\
\hline
\end{tabular}

Keterangan : Angka-angka dalam kolom dan baris rata-rata pada jumlah gabah isi per malai dan bobot 1.000 butir gabah pada agroekosistem dan sistem tanam yang diikuti huruf yang sama tidak berbeda nyata menurut LSD $1 \%$ 
Tabel 7. Pengaruh sistem tanam dan agroekosistem terhadap produktivitas padi varietas Inpari 13 di lahan pasang surut dan irigasi Provinsi Riau pada MH 2015 (t/ha)

\begin{tabular}{lccc}
\hline Perlakuan & \multicolumn{3}{c}{ Agroekosistem } \\
Sistem Tanam & Pasang surut & Irigasi & Rata-rata \\
\hline Tegel & 4,43 & 5,68 & $\mathbf{5 , 0 6 a}$ \\
Jarwo $4: 1$ & 5,38 & 6,21 & $\mathbf{5 , 8 0 b}$ \\
Jarwo 2:1 & 5,80 & 6,56 & $\mathbf{6 , 1 8 b}$ \\
\hline Rata-rata & 5,20 & 6,15 & $\mathbf{5 , 6 8}$
\end{tabular}

Keterangan : Angka-angka dalam kolom dan baris ratarata produktivitas pada agroekosistem dan sistem tanam yang diikuti huruf yang sama tidak berbeda nyata menurut LSD $1 \%$.

\section{Sistem Tanam}

Perubahan sistem tanam dari sistem tegel ke Jarwo rata-rata meningkatkan produktivitas padi sebesar 0,93 t/ha (Tabel 9). Peningkatan produktivitas padi akibat penggunaan sistem tanam Jarwo dapat dipahami karena adanya tambahan populasi tanaman (Tabel 8). Rata-rata penambahan populasi akibat penggunaan sistem tanam Jarwo adalah 36.667 rumpun per hektar. Penambahan populasi tersebut menyebabkan jumlah malai per satuan luas lebih tinggi (Mohaddesi et al., 2011; Mondal dan Putch, 2013; Sarlan, 2014). sehingga hasilnya lebih tinggi (Giametri dan Yursak, 2013; Erythrina dan Zaini, 2014; Nakano et al., 2014).

Tabel 8. Populasi tanaman padi berdasarkan sistem tanam di Provinsi Riau pada MH 2015

\begin{tabular}{lcc}
\hline Sistem tanam & \multicolumn{2}{c}{ Populasi tanaman (rumpun/ha) } \\
\cline { 2 - 3 } & Jumlah & Tambahan \\
\hline Tegel & 160.000 & - \\
Jarwo 4:1 & 180.000 & 20.000 \\
Jarwo 2:1 & 213.333 & 53.333 \\
\hline Rata-rata & - & 36.667 \\
\hline
\end{tabular}

Peningkatan produktivitas padi akibat penggunaan sistem tanam Jarwo juga berkaitan dengan jumlah populasi/baris tanaman pinggir. Dalam petakan berukuran $5 \mathrm{~m}$ × $5 \mathrm{~m}$, maka pada sistem tanam tegel hanya ada 2 (dua) baris tanaman pinggir, sedang pada sistem tanam Jarwo rata-rata ada 13 tanaman pinggir. Hasil pengamatan di lapangan memperlihatkan bahwa tanaman pinggir tumbuh lebih baik dan jumlah gabahnya lebih tinggi. Hal ini mungkin disebabkan adanya suplai hara akibat pergerakan air dan tanaman memperoleh sinar matahari yang lebih banyak. Oleh karena itu merapatkan atau memperbanyak tanaman pinggir dalam sistem tanam Jarwo adalah dalam rangka "menjaring" hara yang lebih banyak agar efisiensi pemupukan lebih tinggi (Tabel 5), sehingga daya serap hara tanaman lebih tinggi (Masganti, 2011).

Kelebihan lain sistem tanam Jarwo dengan sistem tanam tegel adalah lebih mudahnya pemeliharaan tanaman akibat tersedianya ruang kosong. Kondisi ini menyebabkan sebagian ruangan terbuka, sehingga menyebabkan tikus "enggan" menyerang tanaman, dan menyebabkan produktivitas lebih tinggi. Jarak antarbaris yang lebih rapat menyebabkan pertumbuhan gulma tertekan (Hasanuzzaman et al., 2009; Nayak et al., 2014) dan hasil padi lebih tinggi (Mohaddesi et al., 2011; Mondal dan Putch, 2013; Nakano et al., 2014).

Penggunaan sistem tanam Jarwo menyebabkan penurunan produksi gas rumah kaca (GRK). Diantara ketiga sistem tanam dalam penelitian ini dilaporkan bahwa sistem tanam tegel menghasilkan GRK yang paling tinggi, diikuti sistem tanam Jarwo 4:1, dan terendah dihasilkan oleh sistem Jarwo 2:1. Oleh karena itu sistem tanam Jarwo menjadi salah satu komponen teknologi utama dalam pengelolaan tanaman terpadu yang ramah lingkungan (Wihardjaka dan Nursyamsi, 2012; Wihardjaka, 2015). Akan tetapi khasiat sistem tanam Jarwo terhadap peningkatan produksi padi harus didukung dengan teknologi pemupukan yang tepat (Husnain et al., 2016).

Dibandingkan dengan sistem tanam Jarwo 4:1, produktivitas padi yang dibudidayakan menggunakan sistem tanam Jarwo 2:1 lebih tinggi, meskipun secara statistik tidak berbeda nyata (Tabel 9), akan tetapi rata-rata tambahan produktivitas mencapai $0,39 \mathrm{t} / \mathrm{ha}$ merupakan angka yang cukup signifikan bagi peningkatan produksi dan pendapatan petani. Peningkatan produktivitas sistem Jarwo 2:1 di lahan irigasi sebesar $0,88 \mathrm{t} / \mathrm{ha}$, lebih rendah dari hasil yang diperoleh Giametri dan Yursak (2013) sebesar 1,0 t/ha. Perbedaan hasil kedua sistem tanam tersebut dapat dipahami karena (a) jumlah populasi tanaman padi yang dibudidayakan menggunakan sistem tanam Jarwo 2:1 lebih tinggi (Tabel 7), dan (b) jumlah baris tanaman pinggir padi yang dibudidayakan menggunakan sistem tanam Jarwo 2:1 lebih banyak. Dalam petakan berukuran $5 \mathrm{~m} \times 5 \mathrm{~m}$, jumlah baris 
tanaman pinggir padi yang dibudidayakan menggunakan sistem tanam Jarwo 2:1 adalah 16 baris, sedang jika menggunakan sistem tanam Jarwo 4:1 hanya 10 baris.

\section{Agroekosistem}

Berdasarkan hasil analisis ragam diketahui bahwa perbedaan agroekosistem menyebabkan perbedaan produktivitas padi. Tabel 6 menjelaskan bahwa produktivitas padi Inpari13 lebih tinggi jika dibudidayakan di lahan sawah irigasi. Hasil ini sejalan dengan hasil yang dilaporkan Masganti (2013), Sarlan (2014), dan Masganti et al. (2016).

Perbedaan produktivitas tersebut dapat dipahami mengingat tingkat kesuburan tanah di lahan sawah irigasi lebih tinggi dari lahan sawah pasang surut (Nurhayati et al., 2012; Masganti, 2011; Sarlan, 2014). Perbedaan tersebut menyebabkan tanaman padi yang dibudidayakan di lahan sawah irigasi tumbuh lebih baik, menghasilkan jumlah anakan dan jumlah malai bernas lebih banyak, sehingga produktivitasnya lebih tinggi (Mohaddesi et al., 2011; Giametri dan Yursak, 2013; Nakano et al., 2014).

Penyebab lain dari lebih rendahnya produktivitas padi yang dibudidayakan di lahan sawah pasang surut adalah adanya sumber keracunan seperti alumunium dan besi. Pengelolaan air yang tidak baik menyebabkan munculnya gangguan berproduksi berupa keracunan besi (Khairullah et al., 2011; Nakano et al., 2014; Wahida, 2014;), sehingga tanaman membentuk anakan, malai, dan gabah isi yang lebih sedikit (Giametri dan Yursak, 2013; Nayak et al., 2014; Sarlan, 2014).

Suplai air secara periodik di lahan sawah pasang surut dapat membawa sebagian hara dari areal pertanaman padi akibat pergerakan air (Masganti, 2011; 2013; Masganti et al., 2016). Jarak tanam yang rapat dapat berfungsi sebagai "barrier" atau penghambat keluarnya hara dari areal pertanaman, sehingga pertumbuhan tanaman padi lebih baik dan hasilnya lebih tinggi. Sedangkan di lahan sawah irigasi pergerakan air diatur melalui saluran irigasi yang tertata baik. Oleh karena itu penggunaan sistem tanam Jarwo di lahan sawah pasang surut meningkatkan produktivitas padi lebih tinggi. Perlu penelitian lebih lanjut tentang khasiat sistem tanam Jarwo pada berbagai tipologi luapan lahan pasang surut.

Tabel 9 menunjukkan bahwa khasiat sistem tanam Jarwo dalam meningkatkan rata-rata produktivitas padi lebih tinggi di lahan sawah pasang surut sebesar 0,45 t/ha. Sistem tanam Jarwo 2:1 meningkatkan produktivitas padi di lahan sawah pasang surut sebesar 1,37 t/ha dan di lahan sawah irigasi sebesar $0,88 \mathrm{t} / \mathrm{ha}$. Perbedaan ini disebabkan efisiensi pemupukan padi di lahan sawah pasang surut lebih tinggi jika populasi tanaman ditingkatkan (Tabel 5). Pada tanah yang miskin, jarak tanam yang rapat atau sempit meningkatkan efisiensi pemupukan. Oleh karena itu pada tanah-tanah yang miskin hara disarankan mempersempit jarak tanam agar tanaman dapat memanfaatkan hara secara optimal (Masganti, 2011).

Hasil penelitian ini juga mengindikasikan bahwa lahan sawah pasang surut berpotensi besar meningkatkan produksi padi di Provinsi Riau melalui perbaikan sistem tanam. Menurut Nurhayati et al. (2016) saat ini luas lahan sawah pasang surut yang ditanami padi sekali setahun adalah 36.608 ha dan yang ditanami dua kali setahun sebesar 6.101 ha, sedangkan sawah irigasi yang ditanami padi sekali setahun adalah 9.801 ha dan yang ditanami dua kali setahun sebesar 2.381 ha. Berdasarkan data tersebut,

Tabel 9. Pengaruh agroekosistem dan sistem tanam terhadap produktivitas padi di Provinsi Riau pada MH 2014 (t/ha)

\begin{tabular}{llcccc}
\hline \multirow{2}{*}{ No. } & \multirow{2}{*}{ Sistem tanam } & \multicolumn{4}{c}{ Agroekosistem } \\
\cline { 3 - 6 } & & \multicolumn{2}{c}{ Pasang surut } & \multicolumn{3}{c}{ Irigasi } \\
\cline { 3 - 6 } & & Produktivitas & Tambahan & Produktivitas & Tambahan \\
\hline 1. & Tegel & 5,43 & - & 5,68 & - \\
2. & Jarwo $4: 1$ & 5,80 & 0,95 & 6,21 & 0,53 \\
3. & Jarwo $2: 1$ & $\mathbf{5 , 2 0}$ & $\mathbf{1 , 1 6}$ & $\mathbf{6 , 1 5}$ & 0,88 \\
\hline & Rata-rata & & & & $\mathbf{0 , 7 1}$ \\
\hline
\end{tabular}


jika budidaya padi menggunakan sistem tanam Jarwo $2: 1$, diperkirakan terjadi penambahan produksi padi per tahun di lahan pasang surut sebesar 66.870 ton dan di lahan irigasi sebesar 12.815 ton.

\section{KESIMPULAN DAN SARAN}

\section{Kesimpulan}

Tinggi tanaman dan produktivitas padi sangat dipengaruhi oleh agroekosistem dan sistem tanam, sedangkan jumlah anakan, jumlah gabah isi per malai, dan bobot 1.000 butir gabah sangat dipengaruhi hanya oleh agroekosistem. Produktivitas padi di lahan irigasi lebih tinggi dari lahan pasang surut.

Perbaikan sistem tanam meningkatkan produktivitas padi. Produksi padi di Provinsi Riau dapat ditingkatkan melalui peningkatan produktivitas dengan menggunakan sistem tanam Jarwo. Dibandingkan dengan sistem tanam tegel, sistem tanam Jarwo 2:1 meningkatkan produktivitas padi lebih tinggi dari sistem tanam Jarwo 4:1. Perbaikan sistem tanam padi di lahan sawah pasang surut meningkatkan produktivitas lebih tinggi $(1,16 \mathrm{t} / \mathrm{ha})$ dari lahan sawah irigasi $(0,71 \mathrm{t} / \mathrm{ha})$.

\section{Saran}

Peningkatan produktivitas padi baik di lahan sawah irigasi maupun sawah pasang surut dapat dilakukan melalui penggunaan sistem tanam Jarwo 2:1. Penerapan sistem tanam ini meningkatkan produktivitas padi 0,88 t/ha di lahan sawah irigasi dan 1,37 t/ha di lahan sawah pasang surut.

Produksi padi Provinsi Riau dapat ditingkatkan melalui penggunaan sistem tanam Jarwo 2:1 sebesar 79.685 ton/tahun, masing-masing diperoleh dari lahan sawah pasang surut sebesar 66.870 ton, dan lahan sawah irigasi sebesar 12.815 ton.

\section{DAFTAR PUSTAKA}

Achmad, M. 2012. Pengaruh aksesibilitas penyuluhan dan kredit terhadap efisiensi usahatani padi di Jawa. Jurnal Trikonomika 11(1):69-80.

Adimihardja, A., K. Sudarman, dan D. A. Suriadikarta. 1998. Pengembangan lahan pasang surut: keberhasilan dan kegagalan ditinjau dari aspek fisiko kimia lahan pasang surut. Halaman: 1-10. Dalam Sabran et al. (Eds.). Prosiding Seminar Nasional Hasil $\begin{array}{llr}\text { Penelitian } & \text { Menunjang } & \text { Akselerasi } \\ \text { Pengembangan } & \text { Lahan Pasang } & \text { Surut. } \\ \text { Balitbangtan, } & \text { Puslitbangtan, } & \text { Balittra. } \\ \text { Banjarbaru. } & & \end{array}$

Aislabie, J. and J. R. Dellipe. 2013. Soil microbes and their contribution to soil services. In. Dymond, J. R. (ed). Ecosystem Services in New ZelandCondition and Trends. Manasaki Whemna Press, Lincoln, New Zeland.

Alwi, M., dan D. Nazemi. 2013. Pengaruh pengelolaan air dan pemberian pupuk terhadap hasil padi di lahan pasang surut. Jurnal Tanah dan Iklim 37(2):111-118.

Anwar K dan Mawardi. 2011. Dinamika tinggi muka air dan kemasaman air pasang surut saluran sekunder sepanjang sungai Barito. Jurnal Tanah dan Iklim. Edisi Khusus: 1-12.

BBSDLP. 2018. Peta Arahan Penggunaan Lahan. Balai Besar Sumberdaya Lahan Pertanian, Bogor. 116 halaman.

BPS Provinsi Riau. 2015. Riau Dalam Angka. Badan Pusat Statistik Provinsi Riau. Pekanbaru. 328 halaman.

Badan Pusat Statistik. 2020. Luas Panen dan Produksi Padi di Indonesia. Berita Resmi Statistik No. 16/02/XXIII 12 halaman. BPS Jakarta.

Bustaman, S. 2014. Penguatan kelembagaan Gapoktan PUAP dalam penerapan teknologi padi spesifik lokasi. J. Penelitian dan Pengembangan Pertanian 33(1):35-46.

Dariah, A., S. Sutono, N. L. Nurida, W. Hartatik, dan E. Pratiwi. 2015. Pembenah tanah untuk meningkatkan produktivitas lahan pertanian. Jurnal Sumberdaya Lahan 9(2):67-84.

Dinas Tanaman Pangan Hortikultura dan Perkebunan Provinsi Riau. 2017. Laporan Tahunan 2017. Pekanbaru. 136 halaman.

Erythrina dan Z. Zaini. 2014. Budidaya padi sawah sistem jajar legowo:tinjauan metodologi untuk mendapatkan hasil optimal. J. Penelitian dan Pengembangan Pertanian 33(2):79-86.

Erythrina. 2016. Bagan warna daun:alat untuk meningkatkan efisiensi pemupukan nitrogen pada tanaman padi. J. Penelitian dan Pengembangan Pertanian 34(1):1-10. 
Eviati, dan Y. Sulaiman. 2009. Petunjuk Teknis Analisis Tanah, Tanaman, Air, dan Pupuk. Balai Penelitian Tanah. Badan Penelitian dan Pengembangan Pertanian. Kementerian Pertanian. 234 halaman.

Giametri, Y., dan Z. Yursak. 2013. Keragaan komponen hasil dan produktivitas padi sawah varietas Inpari 13 pada berbagai sistem tanam. Widyariset 16(3):481-488.

Gomez, K. A., dan A. A. Gomez. 1995. Prosedur Statistik untuk Penelitian Pertanian. Edisi Kedua. Diterjemahkan oleh Sjamsuddin E., dan J. S. Baharsjah. Universitas Indonesia. Jakarta. 680 halaman.

Hairani, A., Y. Raihana, dan Masganti. 2017. Lahan pasang surut:pertanian masa depan Indonesia. Hlm.:50-72 Dalam Masganti et al (Eds.). Agroekologi Rawa. IAARD Press, Badan Litbang, Jakarta.

Hartatik, W., Husnain, dan L. R. Widowati. 2015. Peranan pupuk organik dalam peningkatan produktivitas tanah dan tanaman. $J$. Sumberdaya Lahan (2):107-120.

Hasanuzzaman, M., K. Nahar, T. S. Roy, M. Z. Hussain, and J. U. Ahmed. 2009. The dynamic and dry matter production of transplanted rice as affected by plant spacing and number of seedling per hill. Acad. J. Plant Scinece 2(3):162-168.

Helmi. 2015. Peningkatan produktivitas padi lahan rawa lebak melalui penggunaan varietas unggul padi rawa. Jurnal Pertanian Tropik 2(2):78-92.

Husnain, D. Nursyamsi, dan M. Syakir. 2016. Teknologi pemupukan mendukung Jarwo Super. Jurnal Sumbedaya Lahan 10(1):1-10.

Khairullah, I. L. Indrayati, A. Hairani dan A. Susilawati. 2011. Pengaturan waktu tanam dan tata air untuk mengendalikan keracunan besi pada tanaman padi di lahan rawa pasang surut sulfat masam potensial tipe B. Jurnal Tanah dan Iklim, Edisi Khusus Rawa, Juli 2011.

Koesrini, M. Saleh dan D. Nursyamsi. 2013. Keragaan varietas Inpara di lahan rawa pasang surut. Pangan 22(3):221-227.
Masganti. 2010. Strategi peningkatan kontribusi lahan pasang surut dalam penyediaan beras di Kalimantan Tengah. Halaman: 35-47. Dalam Jamal et al. (Eds.). Prosiding Seminar Nasional Inovasi Teknologi Pertanian Mendukung Ketahanan Pangan dan Agribisnis Perdesaan. Buku II.

Masganti. 2011. Perbedaaan daya serap hara beberapa varietas unggul padi pada tipe lahan berbeda di lahan pasang surut. Penelitian Pertanian Tanaman Pangan 30(1):23-29.

Masganti. 2013. Teknologi inovatif pengelolaan lahan suboptimal gambut dan sulfat masam untuk peningkatan produksi tanaman pangan. Pengembangan Inovasi Pertanian 6(4):187197.

Masganti, Wahyunto, Ai Dariah, Nurhayati, dan Y. Rachmiwati. 2014. Karakteristik dan potensi pemanfaatan lahan gambut terdegradasi di Provinsi Riau. Jurnal Sumberdaya Lahan 8(1):47-54.

Masganti, M. Alwi, dan Nurhayati. 2015. Pengelolaan air untuk budidaya pertanian di lahan gambut: kasus Riau. Halaman:62-87. Dalam Noor, M. et al. (Eds.). Pengelolaan Air di Lahan Rawa Pasang Surut: Optimasi Lahan Mendukung Swasembada Pangan. IAARD Press, Badan Litbang, Jakarta.

Masganti, Nurhayati, dan Nurmili. 2016. Peningkatan produktivitas padi di lahan pasang surut dengan pupuk $\mathrm{P}$ dan kompos jerami. Jurnal Tanah dan Iklim 40(1):17-24.

Masganti, H. Sosiawan, dan A. Susilawati. 2019. Teknologi peningkatan produktivitas padi di lahan rawa mendukung kedaulatan pangan. Hlm.:252-273 Dalam Masganti et al (Eds.). Sumberdaya Lahan Rawa: Dukungan Teknologi Menuju Lumbung Pangan Dunia. IAARD Press, Badan Litbang, Jakarta.

Mohaddesi, A., A. Abbasian, S. Bhakshipour, and H. Aminpanah. 2011. Effect of different level of nitrogen and plant spacing on yield, yield components and physiological indices in hig yield rice. Aqmer-Eur J. Agric. Environ 10:893-900.

Mondal, M. M. A., and A. B. Putch. 2013. Optimizing plant spacing for modern rice varieties. Int. J. Agric. Biol. 15:175-178. 
Mulyani, A., K. Dwi, D. Nursyamsi, dan A. Fahmjudin. 2016. Konversi lahan sawah Indonesia sebagai ancaman terhadap ketahanan pangan. Jurnal Tanah dan Iklim 40(2):1-7.

Nakano, H., I. Hattori, and S. Morita. 2014. Yield and nutritive value respon to row spacing and cultivar in forage rice. Grassland Sci.60(1):5562.

Nurhayati, A. Jamil, R. F. Zona, Jakoni, A. S. Alim, Elfiani, dan Impersi. 2012. Buku Rekomendasi Pemupukan Padi Sawah pada 9 (sembilan) Kabupaten Lokasi Program OPRM di Provinsi Riau. BPTP Riau. Pekanbaru. 68 halaman.

Nurhayati, Masganti, Rachmiwati Yusuf, dan Ade Yulfida. 2016. Potensi ketersediaan lahan untuk peningkatan produksi padi di Provinsi Riau. Jurnal Sumberdaya Lahan. Edisi Khusus Desember 2016:1-6.

Nuryanti, S., dan D. K .S. Swastika. 2011. Peran kelompoktani dalam penerapan teknologi pertanian. Forum Penelitian Agro Ekonomi 29 (2):115-128.

Ompusunggu, G. P, G. Hardy, dan Razali. 2015. Pemetaan status C-organik tanah sawah di Desa Sei Bamban, Kecamatan Sei Bamban Kabupaten Serdang Bedagai. Jurnal Agroekoteknologi. 4(1):1830-1837.

Rina, Y., dan Koesrini. 2016. Tingkat adopsi varietas Inpara dan Margasari di lahan rawa pasang surut. Jurnal AGROS 18(1):65-80.

Sarlan. 2014. Pengelolaan Hara Spesifik Lokasi Mendukung Sistem Produksi Padi Berkelanjutan. Badan Litbang Pertanian. Jakarta. 63 halaman.

Sutarno. 2012. Kontribusi varietas unggul baru pada usahatani padi dalam rangka meningkatkan keuntungan petani. Jurnal SEPA 9(1):83-89.

Syahyuti. 2014. Implementasi kebijakan untuk mengoptimalkan peran penyuluh pertanian swasta di Indonesia. Jurnal Analisis Kebijakan Pertanian 12(1):19-34.

Wahida, A. Y. 2014. Peran Bahan Organik dan Tata Air Mikro terhadap Kelarutan Besi, Emisi $\mathrm{CH}_{4}$, Emisi $\mathrm{CO}_{2}$, dan Produktivitas padi di Lahan
Sulfat Masam. Disertasi. Program Pascasarjana UGM Yogyakarta. 173 halaman.

Wihardjaka, A., dan D. Nursyamsi. 2012. Pengelolan tanaman pada padi sawah yang ramah lingkungan. Pangan 21(2):185-195.

Wihardjaka, A. 2015. Mitigasi emisi gas metana melalui pengelolaan lahan sawah. Jurnal Penelitian dan Pengembangan Pertanian 34(3):95-104. 